\title{
A Study on the Effect of Solar Fraction on the Environmental Performance of Solar Air-Conditioning by an Adsorption Chiller
}

\author{
F. Basrawi ${ }^{1, *}$, K. Habib ${ }^{2}$, H. Ibrahim ${ }^{1}$ and G.C. Lee ${ }^{1}$ \\ ${ }^{1}$ Universiti Malaysia Pahang, Faculty of Mechanical Engineering, 26600 Pekan Pahang, Malaysia \\ ${ }^{2}$ University Technology Petronas, Department of Mechanical Engineering, Bandar Seri Iskandar, 31750 \\ Tronoh, Perak, Malaysia
}

\begin{abstract}
Solar air-conditioning (AC) is a sustainable air-conditioning system but a back-up heater is needed because a solar AC has intermittent output. This study presents the effect of ratio of heat delivered by solar to the total heat delivered to an adsorption chiller (solar fraction) on the environmental performance of a solar AC system. This AC system need covers cooling demand for an office building in Malaysia. Cooling demand of the building was simulated using well-known building energy analysis software, Equest. Flat-plate collectors and an adsorption chiller were the main component of the solar AC system. Flat-plate collecters were simulated using another software, Watsun, and the adsorption chiller was based on the author simulation model that is comparable with other studies. Environmental performance was analyzed by emission ratio of a boiler and power plants. Solar fraction of $0.33,0.74$ and 0.98 were studied. It was found that solar AC by an adsorption chiller can cover the cooling demand of the office building throughout the year. It was also found that a gas fired boiler is a better auxiliary heater than an electric heater because of the direct conversion of heat from fuel. Less emissions is emited at higher SF compared to conventional AC for all cases of back-up heater. A solar AC must has solar fraction higher than $74 \%$ to ensure it emits less emissions than a conventional AC system.
\end{abstract}

Keywords: Solar cooling, adsorption chiller, solar fraction, emissions.

\section{INTRODUCTION}

Solar Air-Conditioning (AC) system is an attractive way for $A C$ because it is environmental friendly and it can reduce operational cost. Solar AC can be achieved by either using an absorption chiller or an adsorption chiller. The former is more common because it has higher COP and lower price, but it requires higher driving temperature. The later is comparatively less used because it has lower COP and higher price, but it can be driven at lower temperature. This study focuses on the adsorption chiller because it has lower driving temperature that lower price flat-plate collecter can provide.

Adsorption chiller can operate at the temperature range of 50 to $99^{\circ} \mathrm{C}$. Hot water at that temperature range can be supplied by flat-plate collectors. Since the insolation received on the earth surface fluctuates due to day/night and sunny/cloudy cycle, an auxiliary heater that consumes fossil fuel or electricity needs to be operated to increase the hot water temperature. The use of a large collector can reduce the use of fuel/electricity in an auxiliary heater, and therefore it decreases the emissions. However, it will increase the capital cost of the solar AC which is the main problem in penetrating solar $A C$ to the market. In contrast, the

*Address correspondence to this author at the Universiti Malaysia Pahang, Faculty of Mechanical Engineering, 26600 Pekan Pahang, Malaysia;

Tel: +6019-959 1819; Fax: +609-424-6222; E-mail: mfirdausb@ump.edu.my size of solar collector cannot be too small because it can increase the use of fuel/electricity in an auxiliary heater, and therefore emissions emitted by the solar AC can be higher compared to a conventional vapor compression AC. Thus, it is important to know the effect of solar fraction on the performance of a solar AC system, and clarify the lowest solar faction that a solar $A C$ is still environmentally friendly compared to a conventional AC.

Many studies have been carried out on the innovative design of adsorption chillers [1-3], and analysis on the performance of adsorption chiller at different conditions [4-6], but only a few studies have been carried out on the environmental performance of an adsorption chiller. However, from the literature reviewed there is no study focusing on the effect of solar fraction on the performance of solar cooling by adsorption route. Thus, the main objective of this study is to investigate how the solar fraction will effect the environmental performance of a solar AC system by adsorption route. Cooling load of an office building in Kuala Lumpur was simulated using Equest. The amount of heat and its temperature were then calculated using the cooling demand and performance of the adsorption chiller. Then, the AC load was covered with a flat-plate collecter with various area (solar fraction). Finally, emissions of each solar fraction was calculated and compared to the conventional $A C$ system. 


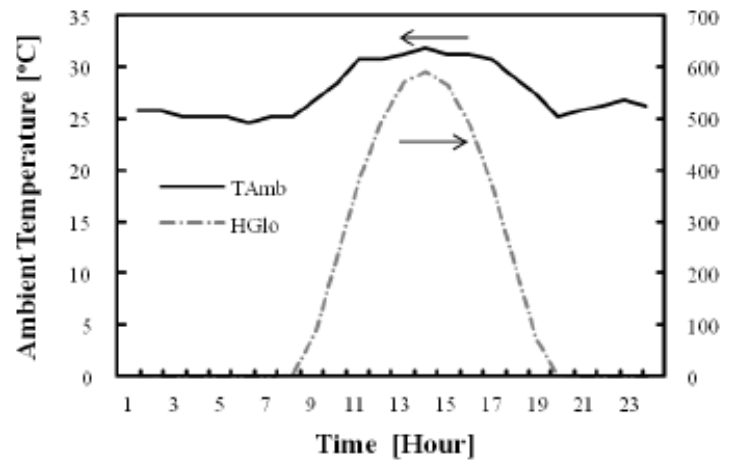

(a) Weather throughout a day

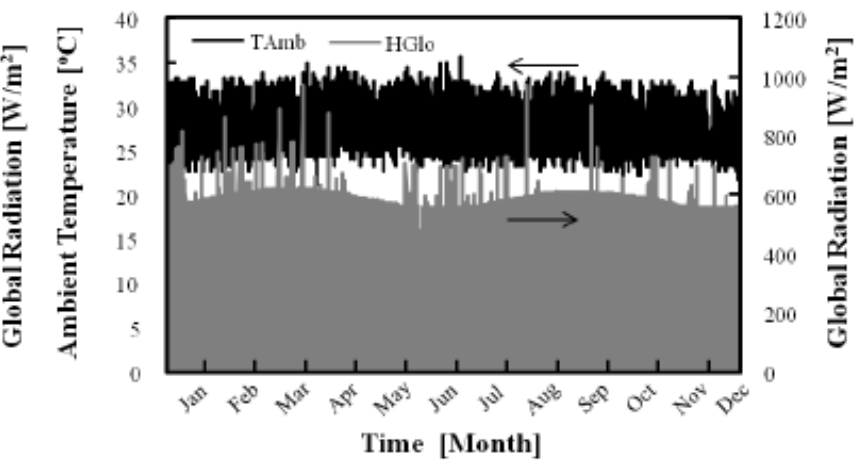

(b) Weather throughout a year

Figure 1: Ambient temperature and global radiation data.

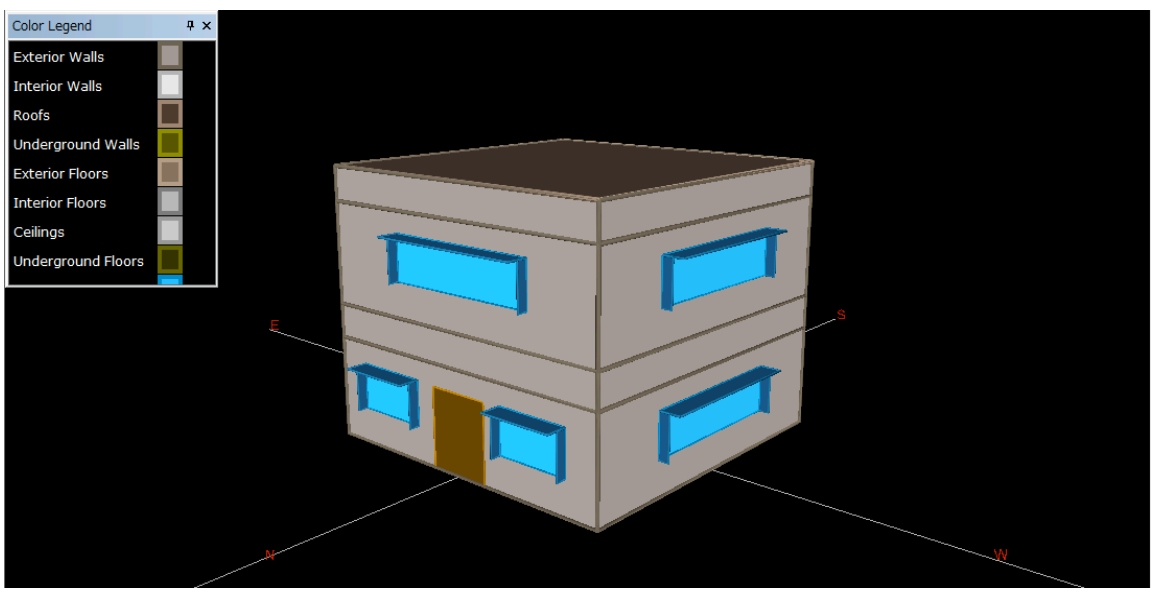

Figure 2: Overall image of the simulated office building.

\section{MATERIALS AND METHODS}

\subsection{Location and Climatic Data}

The location of study is Kuala Lumpur, at $3.1357^{\circ}$ $\mathrm{N}, 101.6880^{\circ} \mathrm{E}$. The weather data used was hourly weather data from ASHRAE International Weather for Energy Calculation (IWEC).

As shown in Figure 1, hourly average ambient temperature is around $24-35^{\circ} \mathrm{C}$ and hourly average solar radiation is $450-1000 \mathrm{~W} / \mathrm{m}^{2}$. It was also found that radiation varies slightly, lower in May, then increased towards peak in August, decreasing again towards November, and increasing again towards February.

\subsection{Building Cooling Load}

The cooling load of the building was simulated using a well known building energy analysis, Equest. Building simulated was a two-storey office building as shown in Figure 2. The parameters used for the calculation are shown in Table 1. There was no insulation material used for the wall and ceiling because this is the actual practice in Malaysia.
Table 1: Parameters of the Simulated Office Building

\begin{tabular}{|c|c|c|}
\hline Building shape & & Rectangle \\
\hline Building orientation & & North \\
\hline Running Hours & hour & $9(8: 00-17: 00)$ \\
\hline Wall layer & & $\begin{array}{c}\text { Plaster-Clay Brick- } \\
\text { Plaster }\end{array}$ \\
\hline Width & $\mathrm{m}$ & 9.14 \\
\hline Gross Area & $\mathrm{m}^{2}$ & 167 \\
\hline Building Area & $\mathrm{m}^{2}$ & 183.5 \\
\hline Wall height & $\mathrm{m}$ & 2.7 \\
\hline Ceiling to floor height & $\mathrm{m}$ & 0.91 \\
\hline
\end{tabular}

\subsection{Solar Water Heater}

The schematic diagram of the overall system is shown in Figure 3. Heat is collected by the flat-plate collector and it is stored in the hot water tank through a heat exchanger. Then, heat is supplied to the adsorption chiller through another heat exchanger. There is an auxiliary heater between hot water tank and adsorption chiller. If less heat is collected from the flat-plate collector to achieve desired cooling, the 
Table 2: Parameters for Different Solar Fraction

\begin{tabular}{|c|c|c|c|c|}
\hline Solar Fraction & Panel Area (No of Panel) & Pump Flow Rate & Pipe Length & Tank Volume \\
\hline \hline- & $\mathrm{m}^{2}($ Unit) & $\mathrm{kg} / \mathrm{s}$ & $\mathrm{m}$ & $\mathrm{m}^{3}$ \\
\hline 0.33 & $19.9(10)$ & 0.44 & 52 & 1.0 \\
\hline 0.74 & $39.8(20)$ & 0.88 & 80 & 2.0 \\
\hline 0.98 & $59.7(30)$ & 1.32 & 108 & 3.0 \\
\hline
\end{tabular}

auxiliary heater will operate. It should be noted that the efficiency of heat exchangers and auxiliary heater were assumed to be 0.8 constant.

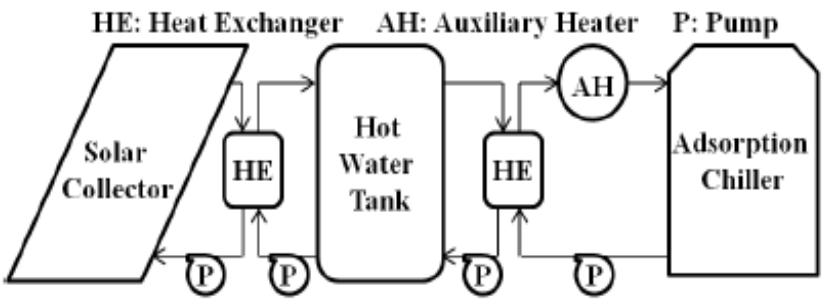

Figure 3: Schematic diagram of the solar water heater.

10,20 and 30 panels were assumed to be used in solar fraction of $0.33,0.74$ and 0.98 , respectively. Basic parameters for water heater system in all solar fractions are shown in Table 2. When the solar fraction increases other parameters including panel area, pump flow rate, pipe length and hot water tank volume also increase.

\subsection{Flat-Plate Collector}

A glazed flat-plate collector with an area of $1.99 \mathrm{~m}^{2}$ each with mass flow rate of $0.044 \mathrm{~kg} / \mathrm{s}$ was used in this study. Actual commercial flat-plate was adopted as the model of the collector. Table $\mathbf{3}$ shows the important parameters of the flat-plate collector.

Table 3: Basic Parameters of the Flat-Plate Collector

\begin{tabular}{|c|c|c|}
\hline Type & & Glazed flat-plate \\
\hline \hline Dimension & $\mathrm{m}$ & $2.016 \times 0.985 \times 0.077$ \\
\hline Groos Area & $\mathrm{m}^{2}$ & 1.99 \\
\hline Dry Weight & $\mathrm{kg}$ & 34 \\
\hline Nominal flow rate & $\mathrm{kg} / \mathrm{s}$ & 0.044 \\
\hline Tilt angle & $\circ$ & 10 \\
\hline
\end{tabular}

\subsection{Adsorption Chiller}

A double bed silica gel-water with maximum cooling capacity of $16 \mathrm{~kW}$ was used in this study. Parameters of the adsorption chiller are shown in Table 4. Since an adsorption chiller is commonly used when the ambient temperature is hot (cooling), the heat sink is usually almost constant. Thus, COP and cooling output can be simply estimated by only using the regeneration temperature as shown in equations below.

$C O P=2.19+\left(-68 / T_{\text {reg }}\right)-0.0105 \times T_{\text {reg }}$

$Q_{\text {cool }}=0.136 \times T_{\text {reg }}^{2}+0.3768 \times T_{\text {reg }}+53.704$

where $T_{\text {reg }}$ is regeneration temperature $\left[{ }^{\circ} \mathrm{C}\right]$.

Table 4: Parameters of the Adsorption Chiller

\begin{tabular}{|c|c|c|}
\hline Mass of the adsorbent, $m_{a}$ & $\mathrm{~kg}$ & 40 \\
\hline $\begin{array}{c}\text { Heat transfer coefficient and Area of the } \\
\text { bed, } U A_{\text {bed }}\end{array}$ & $\mathrm{kW} / \mathrm{K}$ & 3.50 \\
\hline $\begin{array}{c}\text { Heat transfer coefficient and Area of the } \\
\text { evaporator, } U A_{\text {eva }}\end{array}$ & $\mathrm{kW} / \mathrm{K}$ & 4.87 \\
\hline $\begin{array}{c}\text { Heat transfer coefficient and Area of the } \\
\text { condenser, } U A_{\text {con }}\end{array}$ & $\mathrm{kW} / \mathrm{K}$ & 15.33 \\
\hline Mass of the condenser, $m_{c o n}$ & $\mathrm{~kg}$ & 24.28 \\
\hline Mass of the evaporator, $m_{\text {eva }}$ & $\mathrm{kg}$ & 12.45 \\
\hline $\begin{array}{c}\text { Specific heat of the adsorber, } C_{p, a} \\
\text { Latent heat of working fluid, } h_{f g}\end{array}$ & $\mathrm{~kJ} / \mathrm{kgK}$ & 2800 \\
\hline $\begin{array}{c}\text { Specific heat of the heat exchanger, } \\
C_{p, \text { hex }}\end{array}$ & $\mathrm{kJ} / \mathrm{kgK}$ & 0.95 \\
\hline
\end{tabular}

\subsection{Solar Fraction and Emissions Analysis}

Heat to drive the adsorption chiller are from solar and auxiliary heater. Solar fraction is defined as the ratio of solar energy to the total energy delivered. Solar fraction $S F$ can be calculated by the following equations:

$S F=\frac{Q_{S W H}}{Q_{\text {del. }}}=\frac{Q_{\text {del. }}-Q_{A H}}{Q_{\text {del. }}}$

where $Q_{S W H}$ is heat from solar water heater $[\mathrm{kW}], Q_{\text {del. }}$ is heat load delivered [kW] and $Q_{A H}$ is heat from auxiliary heater $[\mathrm{kW}]$.

Both Solar AC and conventional AC release emissions, either on site or from a power plant that 
Table 5: Emissions Rate for Typical Coal-Fired Steam Turbine (CST), Combined Cycle Gas Turbine (CCGT) and Natural Gas Fired Boiler (Boiler)

\begin{tabular}{|c|c|c|c|}
\hline \multirow{3}{*}{$\mathrm{CO}_{2}$} & CST & $\mathrm{g} / \mathrm{kWh}_{\mathrm{p}}$ & 965 \\
\cline { 2 - 4 } & CCGT & $\mathrm{g} / \mathrm{kWh}_{\mathrm{p}}$ & 363 \\
\cline { 2 - 4 } & Boiler & $\mathrm{g} / \mathrm{kWh}$ th & 201 \\
\hline \multirow{3}{*}{ NOx } & CST & $\mathrm{g} / \mathrm{kWh} \mathrm{h}_{\mathrm{p}}$ & 1.7 \\
\cline { 2 - 4 } & CCGT & $\mathrm{g} / \mathrm{kWh}_{\mathrm{p}}$ & 0.20 \\
\cline { 2 - 4 } & Boiler & $\mathrm{g} / \mathrm{kWh}_{\mathrm{th}}$ & 0.22 \\
\hline \multirow{2}{*}{$\mathrm{CO}$} & $\mathrm{CST}$ & $\mathrm{g} / \mathrm{kWh}_{\mathrm{p}}$ & 0.07 \\
\cline { 2 - 4 } & CCGT & $\mathrm{g} / \mathrm{kWh}_{\mathrm{p}}$ & 0.07 \\
\cline { 2 - 4 } & Boiler & $\mathrm{g} / \mathrm{kWh}_{\mathrm{th}}$ & 0.12 \\
\hline
\end{tabular}

supplies electricity. If electricity powered auxiliary heater or conventional AC is used, typical emissions rate from power plants were considered, whereas when natural gas fired auxiliary heater is used, typical emissions rate from a natural gas boiler was considered. Two types of power plants were considered; the common Coal Steam Turbine (CST) or the high-end Combined Cycle Gas Turbine (CCGT) plant. For an electric heater, emissions can be calculated as below:

$m_{n}=P e_{A H} \times E R_{n}$

$m_{n}=\frac{Q_{A H}}{\eta_{\text {elec. } A H}} \times E R_{n}$

where $P e_{A H}$ is power consumed by the electric heater [kWhp], $E R n$ is emission rate $\left[\mathrm{g} / \mathrm{kWh}_{\mathrm{p}}\right], Q_{A H}$ is heat generated $\left[\mathrm{kWh}_{\mathrm{th}}\right]$, and $\prod_{\text {elec.AH }}$ is efficiency of the electric heater [-]. For a gas fired boiler, emissions can be calculated as below:
$m_{n}=Q_{A H} \times E R_{n}$

where $n$ denotes type of emissions. Emissions rate of these energy systems are shown in Table 5 [7]. It should be noted that efficiency of electric heater and gas fired boiler were 0.80 constant, and COP for the conventional $\mathrm{AC}$ was assumed to be 3.0 constant.

\section{RESULTS AND DISCUSSION}

\subsection{Heat Balance of the System}

Figure 4 shows the heat balance between heat demand/delivered, heat from solar and auxiliary energy for a single day, 1st February.

Result for solar fraction from $0.33,0.74$ and 0.98 are shown in Figure $\mathbf{4}(\mathbf{a}, \mathbf{b})$ and (c), respectively. As shown in the figures, when the solar fraction increased, the portion of heat from solar increased, whereas the

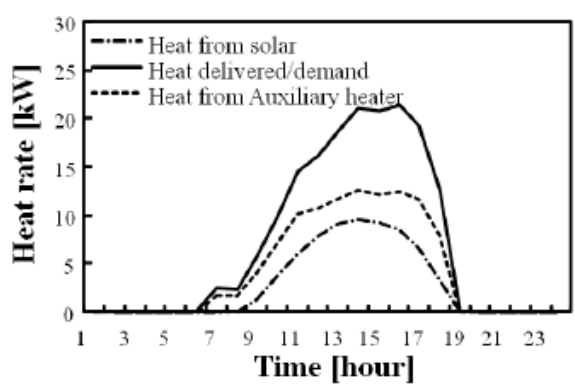

(a) Solar fraction $=0.33$

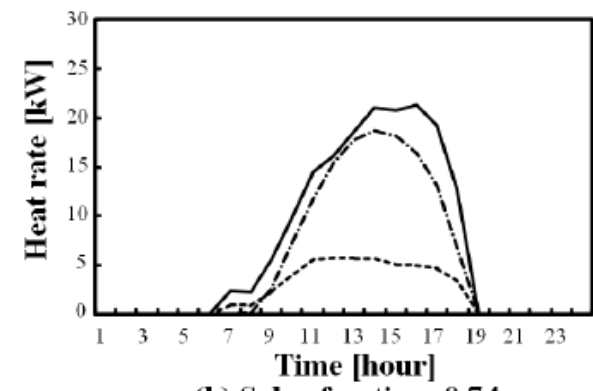

(b) Solar fraction $=0.74$

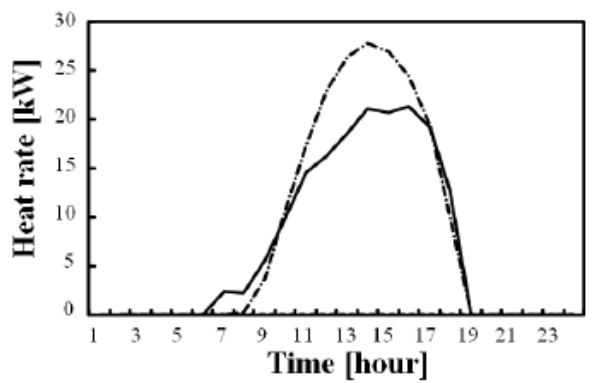

(c) Solar fraction $=0.98$

Figure 4: Heat balance throughout a day for different solar fraction. 
auxiliary energy decreased. However, it was found that heat balance was not totally matched especially for solar fraction of 0.98 , where heat from solar is higher than heat demand. This is because of the existence of the hot water tank where heat was stored, and also because of the target temperature in which the quality of the heat was also considered. Thus, amount of heat from solar was sometimes higher and sometimes lower than the heat demand/delivered.

The result of heat balance throughout the year had similar trend with the result for a single day, auxiliary energy decreased when solar fraction increased. The different was there was a slight fluctuation of auxiliary energy, due to variation of solar radiation throughout the year. Even the highest solar fraction $(S F=0.98)$ still need auxiliary energy from March to September in which the solar radiation was comparatively lower.

\subsection{Emissions from the Systems}

Comparison of emissions released between solar $A C$ with different SF, and conventional $A C$ are shown in Figure 5. Results of $\mathrm{CO} 2, \mathrm{NOx}$ and $\mathrm{CO}$ emissions are shown in Figure $\mathbf{5}(\mathbf{a}, \mathbf{b})$ and (c), respectively. As stated in section 2.6, for an electric heater, electricity was supplied by CST or CCGT.

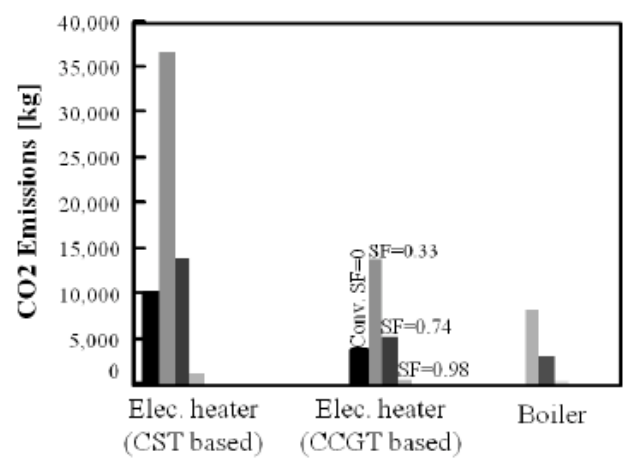

(a) $\mathrm{CO2}$ Emissions
It was found that in overall, the electric heater (CST based) had the highest $\mathrm{CO} 2$ and NOx emissions, and the electric heater (CCGT based) and the boiler had a comparable level of emissions, except for $\mathrm{CO}$. This shows that the boiler is a better solution of auxiliary heater in terms of environmental performance. This is because heat is generated directly from fuel at higher conversion efficiency compared to electric heater.

It was also found that all types of emissions decreased when SF increased compared to conventional AC for all cases of back-up heaters. However, all emissions types released from the solar $A C$ were higher than the vapour compression $A C$, especially when SF is lower than $74 \%$ for all cases.

This clarifies that a solar AC must has solar fraction higher than $74 \%$. If not, more energy is actually used in the back-up heater and resulting more emissions released compared to the conventional $A C$ system and cancel-out the benefit of solar AC, which is a sustainable AC system.

\section{CONCLUSIONS}

A gas fired boiler is a better auxiliary heater than an electric heater because of the direct conversion of heat from fuel.

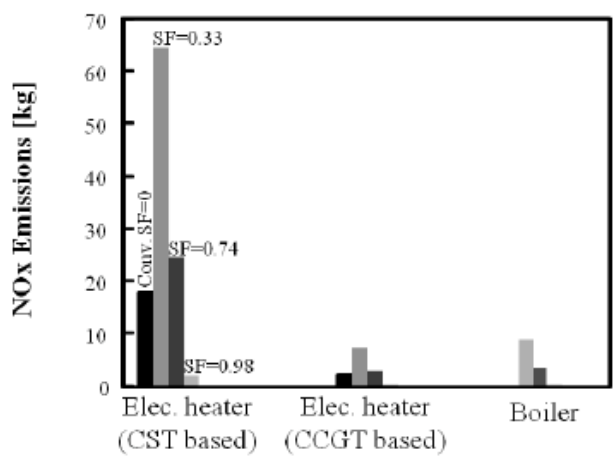

(b) NOx Emissions

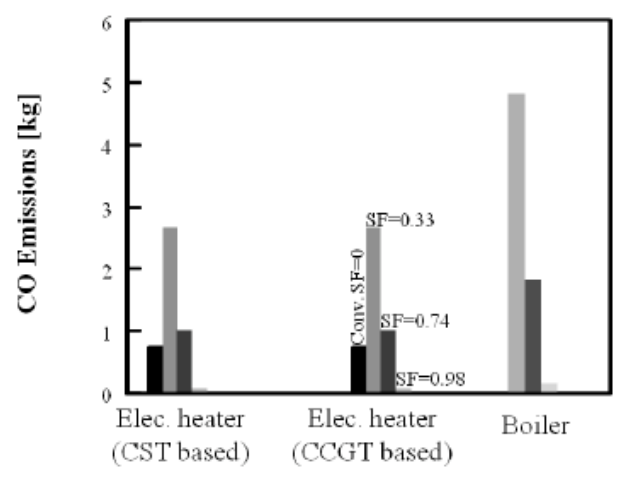

(c) CO Emissions

Figure 5: Result of emissions analysis. 
All types of emissions decreased when solar fraction (SF) increased compared to conventional $A C$ for all cases of back-up heater.

A solar AC must has SF higher than $74 \%$ to ensure it emit less emissions than a conventional $A C$ system.

\section{ACKNOWLEDGEMENT}

The authors would like to thank Universiti Malaysia Pahang for the financial support under RDU1203101.

\section{REFERENCES}

GK. Qian S, Hwang Y, Rademacher R, Chun H. Cyclic steady state performance of adsorption chiller with low regeneration temperature zeolite. Energy 2013; 60: 517-526. http://dx.doi.org/10.1016/j.energy.2013.08.041

[2] RK. Ahmed RMR. Physical and operating conditions effects on silica gel/water adsorption chiller performance. Applied Energy 2012; 89: 921-929.
[3] IS. Yuriy IA, llya SG, Lambert MA, Beyene A. Optimization of adsorption dynamics in adsorptive chillers: Loose grains configuration. Energy 2012; 46: 484-492. http://dx.doi.org/10.1016/i.energy.2012.08.001

[4] TH. Hamid N, Mahdavikhah M. Bed geometrical specifications effects on the performance of silica/water adsorption chillers. International Journal of Refrigeration 2012; 35: 2261-2274. http://dx.doi.org/10.1016/j.jirefrig.2012.08.017

[5] WR. Lu ZS, Xia ZZ, Lu XR, Yang CB, Ma YC, Ma GB. Study of a novel solar adsorption cooling system and a solar absorption cooling system with new CPC collectors. Renewable Energy 2013; 50: 299-306. http://dx.doi.org/10.1016/j.renene.2012.07.001

[6] MJ. Spencer JD, Gibbons WT, Gluesenkamp K, Ahmed II, Tavemer AM, McGahagan D, Tesfaye M, Gupta C, Boume RP, Monje V, Jackson GS. Design of a combined heat, hydrogen, and power plant from university campus waste streams. International Journal of Hydrogen Energy 2013; 39: 4889-4900.

http://dx.doi.org/10.1016/j.ijhydene.2013.02.021

[7] FA. Strachan N. Emissions from distributed vs. centralized generation: The importance of system performance. Energy Policy 2006; 34: 2677-2689. http://dx.doi.org/10.1016/i.enpol.2005.03.015

Received on 15-12-2014

DOI: http://dx.doi.org/10.15377/2409-5818.2014.02.01.3

(C) 2014 Basrawi et al.; Avanti Publishers.

This is an open access article licensed under the terms of the Creative Commons Attribution Non-Commercial License (http://creativecommons.org/licenses/by-nc/3.0/) which permits unrestricted, non-commercial use, distribution and reproduction in any medium, provided the work is properly cited. 